\title{
Substantiation of the siting of construction facilities in the Central Ecological Zone of the Baikal Natural Area: ecological and economic aspects
}

\author{
Inessa Karnaukh ${ }^{1, *}$, Anna Mikheeva $^{2}$, Svetlana Ayusheeva ${ }^{2}$, and Taisia Bardakhanova $^{2}$ \\ ${ }^{1}$ Plekhanov Russian University of Economics, Ctremyannyj per., 36, Moscow, 117997, Russia \\ ${ }^{2}$ The Baikal Institute of Natural Resources Management, Siberian Branch of the Russian Academy of \\ Sciences, Sakhyanovoi str., 8, Ulan-Ude, 670047, Russia
}

\begin{abstract}
The implementation of cost intensive construction projects is determined by the availability of natural resources and the environmental capacity of areas. The objective of the research consists in the development of a methodological approach to the assessment of the siting of construction facilities in the territories, characterized by ecological limitations and the substantiation of siting acceptability criteria. The authors analyzed the potential risks caused by the siting of construction facilities on the basis of (1) the impact produced by the facilities, used for economic activities, on the environment, and (2) the assessment of ecological and socioeconomic consequences of this impact. The core method of research consists in the integral ranking of territories, based on the environmental capacity of the natural environment's components and the anthropogenic impact, while their reconciliation represents one of the most relevant objectives of environmentally sustainable development of territories. The analytical results, generated by the co-authors, serve as the starting point for the research-based substantiation of the siting of construction facilities, because the following condition serves as the basic criterion: the anthropogenic impact, produced on territories, must not exceed the self-recovery potential of the local natural system.
\end{abstract}

\section{Introduction}

The research and practical need for the development of the patterns for the substantiation of siting of new construction facilities arises quite often. It is used both to assess (1) the socioeconomic and nature-oriented strategies for the development of territories, (2) the efficiency of both implemented and planned actions, and (3) varied compensation expenditures or financial charges. However no unified or universal approaches towards the scientific substantiation of the siting of new construction facilities are available, because the development of some territories has unique features and limitations. Contemporary approaches towards the environmental assessment of the acceptability of the siting of

\footnotetext{
*Corresponding author: inessa506@yandex.ru
} 
facilities [1-3], are analyzed in respect of their compliance with the environmental standards, and their principles comply with the criteria applicable to the "green" economy, ecological business activity, and preservation of the environment's quality.

Substantial anthropogenic impacts, produced on natural environments in the early 80ies of the $20^{\text {th }}$ century, translate into (1) the need for objective validation of the environmental safety of the environment, production processes, food and drinking water, and (2) the intensification of the activities performed by the regulatory authorities [4].

Lake Baikal and its environs maintain a special status, pre-set on the international scale and formulated as the UNESCO Natural Heritage site (1996). A regional law "On the Protection of Lake Baikal" [5] was passed at the level of the Russian Federation. This law is accompanied by several non-legislative acts, limiting economic and other activities, that can produce adverse impact on the ecological system of Lake Baikal $[6,7,8]$. The strictest environmental regulations are applicable to the central ecological zone of the Baikal Natural Area ("the Zone") that accommodates over 66.5 residents in 72 populated localities, including the towns of Severobaikalsk, Babushkin, the settlement of Nizhneangarsk, industrial facilities and transportation routes. These populated localities are situated in the four municipal districts of the Republic of Buryatia (Barguzinsky, Kabansky, Baikalsky, and North-Baikalsky).

The siting of new construction facilities in the Zone is limited by the list of activities, prohibited in the Zone [9], and by the banned construction of industrial facilities, except for some food industry/transport enterprises. Therefore, the objective of this project consists in the research into the feasibility of construction of facilities of social, transport, and nature protection infrastructure.

\section{Overview of literature}

The relevance of the research projects, consisting in the development of approaches towards the study of natural and anthropogenic factors within the areas impacted by construction facilities, is proven by the need to maintain a safe human environment, to commission new residential houses, to develop major industrial facilities and leisure areas $[10,11]$. The spatiotemporal pattern of natural and anthropogenic impacts produced on varied natural environments in the Baikal region is the subject matter of the projects implemented by numerous researchers, including geographers, economists, landscape specialists, and limnologists [12-15]. The basic concepts applied to assess man-caused consequences, influencing the natural environment's quality within habitable territories and the forecasting of inter-temporal changes caused by the siting of new construction facilities were the subject of research covered by several works $[16,17]$. Any transformations of natural landscapes may replace the whole natural complex, and this replacement may produce adverse effect on the local relationship between nature, society and economy [18, 19].

Unlike the domestic method used to assess natural and anthropogenic impacts produced by varied sources, the international methodology represents the identification of the levels of accumulation of chemical elements, particularly heavy metals, by specific components of nature [20]. According to several researchers, the generation of new conditions and requirements, applicable to (1) the implementation of the nation-wide environmental policy, (2) the development of patterns for the implementation of private and private/public programmes and projects, is determined by the principles of "green economy" and "green construction" through the improvement of environmental design, hardscape, and the establishment of special-purpose "green construction" trust funds [21, 22].

The availability of natural resources, their renewability, self-cleaning abilities of elements of the natural environment serve as the limiting and security factors of the 
socioeconomic development of any territory. These properties are mainly responsible for the background pollution of natural objects, the average annual concentration of pollutants in the lower atmospheric layer and in the recreational areas adjacent to Lake Baikal [23].

Concurrently with the setting and zoning of the Baikal natural area, the Federal law № 94-FZ, issued on May 1, 1999, sets the principles for the protection of the Baikal natural area, applicable to the use of natural environments, as well as the procedure for the monitoring and protection of natural complexes. It also sets maximal acceptable impacts on ecological systems $[9,24]$. However, according to several ecological and economic studies of the Baikal natural territory, special institutional requirements applicable to the use of natural resources substantially limit the economic activities, boost production expenditures and direct/indirect production expenses, reduce the value of the tax base in respect of varied budgets [25].

Therefore, presently, there is a need to (1) develop the basis for the optimization of the structure, the standards of environmental management, and the assessment of assimilation properties of the natural environment, (2) reconsider and ease the regulations applicable to the Zone. Nonetheless, any potential changes should neither disrupt the balance between natural and anthropogenic systems, nor amplify anthropogenic impacts and economic losses. The theoretical substantiation of economic losses and methodological fundamentals of the environment-related and economic assessment of consequences, caused by the pollution of the environment, was developed by O.F. Balatsky [26], and elaborated by his successors $[27,28,29]$ in the works written by the scholars employed with the Baikal Institute of Nature Management and Institute of Economics and Industrial Engineering, Siberian Branch of the Russian Academy of Sciences [30,31]. The cost of the environmental footprint, calculated with the help of the values of the economic damage, inflicted on the natural environment due to the deterioration of its quality, makes it possible to (1) identify and rank the territories, exposed to maximal economic losses in terms of healthcare, housing and utility sector, agriculture, forestry, (2) set the nature protection investment priorities, and (3) make cross-regional projections in terms of the natural environments, local territories, and economic entities.

Any available methodologies for the forecasting of the cross-regional interaction between the subjects of the Baikal region are based on specialized economic and mathematical models simulating the condition of social, environmental and economic networks and scenarios for the development of territories, including numerical models simulating the pollution of the main waterways (the Selenga, Chikoy, Khilok and other rivers), models simulating the spreading of gaseous admixtures, containing pollutant fields surrounding high and super-high sources, polluting the atmospheric air, and models employed to assess the efficiency of the economic pattern of environmental management $[32,33]$.

The co-authors believe that reduction of ecological and economic risks requires diversification of economic activities, performed alongside the Baikal shoreline, in order to preserve its natural potential and to improve the sustainability of its economic development through the expansion of such production activities as tourism, recreational activity, waste management, protected area maintenance, reforestation and fishery [34].

Therefore, the study of interaction between humans and their environment, assimilation of new territories, siting of new objects of infrastructure requires the application of versatile methods for the comprehensive research and assessment of natural environments, their anthropogenic changes, areas of impact, and the probability of any social, economic, and ecological risks $[35,36]$.

\section{Materials and research methods}


The acceptability of the siting of construction facilities should be analyzed on the basis of the algorithm for the integrated assessment of present and future consequences of construction projects, and this algorithm must be applied to any future construction projects with account for limited resources. The proposed algorithm must comprise:

- The analysis of economic, social, and ecological structures;

- Technological and infrastructural standards;

- Intensification of particular industries;

- The list of social, transportation, environmental management and recreational facilities to be constructed;

- The assessment of present and future impacts;

- The analysis of the effective legislation and regulations applicable to the economic activities;

- The assessment of environmental, socio-economic and other consequences based on the present and future damages;

- The assessment of the environmental capacity of the natural environment.

Traditionally, the shoreline of Lake Baikal, that represents the Zone, has been the best developed area in the Republic of Buryatia, because this area is most densely populated; it has numerous farm households, residential houses and infrastructural facilities. Agricultural areas feature milk farming, cattle breeding, grain growing, catering and hotel businesses which are lucrative for investors (Table 1). Kabansky district has been exposed to excessive anthropogenic impacts: it accommodates a railroad (the Trans-Siberian railway) and a highway (Federal highway M-55); its population density is high (4.3 people/square kilometers), whereas the average population density in Buryatia is 2.8 people/square kilometer. The share of the natural guard fund in the areas, exposed to ecological limitations, varies, while the depreciation of environmental protection facilities is high $(60 \%)$.

Table 1. Ecological and Economic Development of the Zone (2015) (Sources: [37, 38]).

\begin{tabular}{|l|c|c|c|c|c|}
\hline \multicolumn{1}{|c|}{ Values } & Severobaikalsk & $\begin{array}{c}\text { Kabansky } \\
\text { district }\end{array}$ & $\begin{array}{c}\text { Baikalsky } \\
\text { district }\end{array}$ & $\begin{array}{c}\text { Barguzinsky } \\
\text { district }\end{array}$ & $\begin{array}{c}\text { North- } \\
\text { Baikalsky } \\
\text { district }\end{array}$ \\
\hline $\begin{array}{l}\text { Population density, } \\
\text { people/m }\end{array}$ & 216.7 & 4.3 & 1.7 & 1.2 & 0.2 \\
\hline $\begin{array}{l}\text { The area occupied by } \\
\text { grass crops per person, } \\
\text { hectares/person }\end{array}$ & 0.004 & 0.2 & 0.1 & 0.09 & 0.02 \\
\hline $\begin{array}{l}\text { Livestock number per } \\
\text { person, head/person }\end{array}$ & - & 0.3 & 0.1 & 0.6 & 0.06 \\
\hline $\begin{array}{l}\text { Retail trade turnover } \\
\text { per person, thousand } \\
\text { rubles/person }\end{array}$ & 260 & 115.9 & 99 & 41.2 & 79.9 \\
\hline $\begin{array}{l}\text { Catering turnover per } \\
\text { person, thousand } \\
\text { rubles/person }\end{array}$ & 11.6 & 6.6 & 4.3 & 5.4 & 3 \\
\hline $\begin{array}{l}\text { Per-unit value of the } \\
\text { natural guard funds as } \\
\text { part of the value of } \\
\text { fixed assets, \% }\end{array}$ & 12 & 8.42 & 0.05 & - & 0.01 \\
\hline $\begin{array}{l}\text { Emission of pollutants } \\
\text { into the atmosphere, } \\
\text { kg/person }\end{array}$ & 89.6 & 129.9 & 70.8 & 35.8 & 151 \\
\hline $\begin{array}{l}\text { Discharge of liquid } \\
\text { pollutants, kg/person }\end{array}$ & 37.6 & 17.4 & 3.7 & - & 15.6 \\
\hline
\end{tabular}

The component analysis of the condition of natural environments has identified the pollution of the atmospheric air in the residential areas. The pollution is caused by human 
activities, natural processes, forest fires, and the trans-border transport of the polluted air. The air of habitable territories is highly polluted with methylmercaptan, sulphur and nitrogen dioxides, solid aerosols. The problem of protection of the water resources consists in the insufficiency of the natural guard funds; therefore, over $50 \%$ of the water discharged in the Zone $(2.1-2.3$ million square meters) does not comply with the quality standards, as it does not get treated before discharging, or this water is considered "insufficiently treated".

The availability of social facilities in the Zone is governed by the applicable regulations, and their number is deemed sufficient, except for kindergartens. The majority of school buildings and healthcare centres have a heavy wear percentage $(70 \%)$. Some of the buildings fail to comply with the Technical regulations for the safety of buildings and structures.

Electric energy, steam, and hot water are produced in the Zone by boiler houses, consuming solid fuel. In Severobaikalsk, the central steam house that produces thermal energy for urban facilities, has the total capacity of $166 \mathrm{Gcal} /$ hour $(190.7 \mathrm{~mW})$. The percentage of the capture of pollutants is $85 \%$; the wear of the process equipment is $65-$ $70 \%$ there. The steam houses of small towns within the Zone produce insignificant adverse impact on the environment. The majority of the steam houses were commissioned back in the $60 \mathrm{ies}$ and $70 \mathrm{ies}$ of the $20^{\text {th }}$ century; their wear percentage reaches $60-78 \%$. The installed load exceeds the supplied load at almost every steam house, but, given the wear of the equipment, old boilers must be replaced by new ones and heat distribution networks need upgrading.

In Severobaikalsk, sewage treatment plants have an average capacity in terms of the treatment of inflowing organic compounds, and their wear has reached $50 \%$. They represent a three-step sewage treatment system, that has mechanic and biological water treatment steps followed by customized micro-filters and the system of extensive final purification. The town of Severobaikalsk is the main pollutant; it discharges biogenic substances into Lake Baikal. In 2010 - 2014, the amount of biogenic substances, discharged into Lake Baikal, went up; the amount of nitrites went up 5-fold, the amount of nitrates went up 2fold, the amount of phosphates went up 3-fold. Household and soil discharges fail to get sufficiently purified, although they get discharged into the Tyya river that runs into Lake Baikal [39]. Urban discharges of the town of Babushkin pass through a two-step treatment system, that has mechanic and biological steps; therefore, the treatment efficiency is low and it reaches $53 \%$ in terms of the suspended matter (against the design treatment efficiency of 98\%), and the treatment efficiency reaches $25 \%$ in terms of organic substances (against the design treatment efficiency of $99 \%$ ). The discharged water is insufficiently pure and toxic.

The transportation infrastructure of the Zone is characterized by the low density of motor roads, the low stretch of hard and improved roads, the dissatisfactory condition of the road bed. 13 populated localities of the Zone have no hard roads connected to the network of public access roads, which converts into $571 \mathrm{~km}$ of roads to be constructed. The condition of the water transport infrastructure is characterized by the insufficiently developed network of port and dock facilities. Vessel operations are impossible there (bunkering, storage, repair and collection of the bilge water). Low profitability of intraregional air routes determines the insufficient development of the air service infrastructure in the Zone.

The list of social, transportation, and nature protection facilities to be constructed in the Zone has been compiled on the basis of the analysis of the investment strategy of the Republic of Buryatia, area planning schemes of the Republic of Buryatia/municipal districts of the Republic of Buryatia. The need for the social facilities has been identified following the reconciliation of the local social regulations and the number of social facilities available 
in the Zone. Thus, 1,199 preschool children need kindergartens; 203 schoolchildren need schools, and 1006 patients need hospitals. The transportation infrastructure needs motor roads, intra-regional airports, helicopter landing sites, and runways. The construction of railroads means the implementation of projects and the intensification of the railroad traffic at the Baikal-Amur Mainline, including the construction of its second railroad track, the use of the stations inside the Severo-Muisky tunnel at the design capacity; the increase in the number of operations performed by Taksimo and Uoyan stations; the improvement of railroad communications with the gold mining centre Bodaibo in the Irkutsk region, and the construction of the railroad spur to connect Mozgon, Ozerny mining and processing plant, and Novy Uloyan. The prospects for the development of the water transport infrastructure are associated with the construction of a network of port and dock facilities. The anthropogenic impact to be produced by the infrastructural development will consist in the withdrawal of valuable and low-value lands; changes in the terrain; pollution of the atmosphere by hazardous emissions in the course of construction and operation of future roads; pollution of the water environment. Nonetheless, the planned construction of items of the transport infrastructure will not be accompanied by any pro-rated rise in the impact to be produced on the environment. The projected traffic intensity will not exceed the design values, set for the roads of the $3^{\text {rd }}$ and $4^{\text {th }}$ categories, and future operations will not cause the authorized emission values to be exceeded. The pollution of the atmosphere by the emissions, including those in the residential areas, will not exceed the values pre-set in the sanitary and hygienic regulations applicable to the atmospheric air of residential areas.

Therefore, the main facilities, exposed to anthropogenic impacts in the Zone, include housing and public utilities, tourist and recreational facilities, transportation facilities and households. The social, transportation, and power facilities, as well as the public utilities (heat, water supply, and wastewater discharge), recreational facilities, nature protection facilities, safety assurance facilities of the Zone are broken down according to the criteria of adverse impacts produced on environments. According to this breakdown methodology, all facilities must be broken down into four categories, approved by the Government of the Russian Federation. As a result, neither facility is ranked as the First category facility that produces substantial negative impact on the environment of the Zone. Second category facilities, that produce moderately negative impact on the environment, include the boiler house and water treatment works of Severobaikalsk. Third category facilities, that produce insignificant impact on the environment, include the boiler houses of several towns within the Zone, the boiler house of the Baikal reserve, and the water facilities used to discharge water into the water bodies. Fourth category facilities, that produce negative impact on the environment, include the majority of boiler houses in the rural residential areas of the Zone, as they emit below 10 tons of pollutants a year, as well as waste treatment facilities that discharge polluted water onto the terrain.

The planned construction and upgrade of social and transport facilities, public utilities, the implementation of investment projects associated with the intensively developing travel industry of the region serve as a binding precondition for the development of the methodological approach towards the assessment of the siting of construction facilities in the territories exposed to environmental restrictions in terms of the engineering infrastructure, power grids, communication/heat supply networks.

We believe that any new construction project must be deemed acceptable if it takes account of:

1. The natural factor, because the construction of any property must be limited by the natural capacity of specific areas;

2. The anthropogenic factor, or the influence of present and past economic activities on the types and volumes of the construction work. 
The co-authors employ (1) the method of integral assessment of the environmental capacity and the anthropogenic impact and (2) the comparative analysis of the findings to assess the acceptability of new construction facilities. The process of substantiation of new construction projects should comprise the ability of the natural system to regenerate the resources it loses and to neutralize hazardous anthropogenic impacts. The environmental capacity of a natural complex is determined by the dimensions of the air basin, water bodies and flows, land areas and soil reserves, flora and fauna; the intensity of flows forming the chemical, geological, and chemical circulation that renews the content of air basins, water bodies, etc.; the intensity of the interchange of various gases between atmosphere and soil; the intensity of the pure water production, the intensity of soil forming processes, and the intensity of the biota's productivity [40]. Such is the integral characteristic of a territory that translates into maximal anthropogenic impact, endurable by a combination of recipients and environmental systems of a territory without any damage to their structural and functional properties. The environmental capacity of a territory is part of the overall environmental capacity of a territory which is determined by the factor of deviation of the characteristic composition of the environment from its natural level. Any deviation, exceeding the pre-set value, is deemed to be caused by the anthropogenic impacts that have reached the maximal sustainability value of the local natural complex. The integral value of the environmental capacity of natural complexes takes account of the environmental capacity of the atmosphere, water resources, and soils. The authors have employed the following formula to calculate the environmental capacity of a territory:

$$
E_{e}=\sum_{i=1}^{3} E_{i} X_{i} \tau_{i}(i=1,2,3)
$$

where Ee stands for the ecological capacity of a territory, expressed in the units of the anthropogenic impact, or hypothetical tons/year; $\ni_{i}$ stands for the ecological capacity of the environment, tons/year; $\mathrm{X}_{\mathrm{i}}$ is the factor of deviation of the content of the core component in the environment; $\tau_{\mathrm{i}}$ stands for the factor of the relative hazard of admixtures (the factor employed to convert mass into hypothetical tons).

The quantitative assessment of the anthropogenic impact requires the employment of the method of integral assessment of sources of hazard, including the amount of pollutants emitted into the atmosphere and into the water; the formation of industrial and forestryrelated waste; household waste formation, emission of nitrogen and phosphorus into water bodies, emissions of pollutants into the atmosphere by households. The hazard of pollutants, emitted into the atmosphere, may vary. The identification of the overall anthropogenic impact requires the conversion of these values into standard units [41].The following ratios describing the ecological and economic hazard of substances were applied to identify the adjusted amount of pollutants, emitted into the atmosphere: carbon oxide 0.4 , hydrocarbons -0.7 , solid substances -2.7 , nitrogen oxides -16.5 , sulfur dioxide -20 . Pollutants, emitted into the water, were adjusted for comparison purposes through the application of the following special ratios: sulfates, chlorides -0.05 , suspended solids 0.15 , nitrates -0.2 , petrochemicals, fats and oils -20 , phosphor -1 , phenol -550 . The following ratios were applied to identify the adjusted mass of wastes based on the fourth class of hazard: the fifth class of hazard -0.2 ; the fourth class of hazard -1 ; the third class of hazard -2 ; the second class of hazard -3 ; the first class of hazard -7 .

When analyzing the final value of the "anthropogenic impact/environmental capacity ratio" (or the multiplication factor), we take the environmental capacity as the reference value equal to 1 . The multiplication factor, by which the maximal environmental capacity is exceeded, determines the acceptability of new construction facilities:

$$
\mathrm{Ke}=\mathrm{U} / \mathrm{Ee}
$$


where $\mathrm{Ke}$ is the multiplication factor, by which the maximal environmental capacity value is exceeded; $U$ is the environmental capacity of a production facility in the territory, or a combination of the economic withdrawal and damage inflicted on renewable local resources, including the pollution of environments and other types of the anthropogenic suppression of recipients, measured in hypothetical tons a year; and Ee stands for the environmental capacity of a territory, in hypothetical tons a year, as well. There are different values of Ke which are based on the nature of disturbance factors and ranked by the intensity of the anthropogenic impact. In case of $\mathrm{Ke} \leq 0,3$, the environment is deemed safe, and the construction of new facilities is acceptable; in case of $\mathrm{Ke} \approx 1$ or $1<\mathrm{Ke}<2$, the environmental situation is considered critical; in case of $\mathrm{Ke} \geq 10$, no construction facilities are acceptable. Another methodology, applied to evaluate the acceptability of any new construction projects, consists in the assessment of the prior ecological damage; it represents a set of methods, developed by the State Ecological Committee of the Russian Federation [41].

\section{Results}

The findings of our research have proven that the principal criterion of environmental acceptability of construction facilities represents the value of the "environment to economy" or the "nature to production" ratio, in other words, whether the integral anthropogenic impact is below its maximal acceptable value. Following our principle of well-balanced environmental management, our concept can be represented as the mechanism employed to limit all current and future production capacities within a particular territory by the environmental capacity of the local natural complex.

Within the framework of this project, the co-authors benchmarked the anthropogenic impact against the environmental capacity of five municipal districts in the Zone. The results of comparative assessments are provided in Figure 1.

Fig. 1. The results of the benchmarking of the anthropogenic impact against the environmental capacity in the municipal districts of the Zone (a logarithmic scale)

The Zone accommodates no major industrial enterprises; therefore, the economic damage, inflicted upon the environment by the local economics activities, is insignificant. The value of the economic damage, broken down by the components of the natural environment, takes account of the ecological situation and the environmental significance of the area, exposed to the anthropogenic impact, as well as the hazard of respective 
pollutants. For the purpose of identifying the anthropogenic impact all constituents were converted into standard units. In our calculations, we employed the environmental and economic value of the per-unit damage as the hypothetical ton of the adjusted mass of polluted air, water, soil, and land resources. The insignificance of any prior environmental damage serves as the criterion of acceptability of any new construction projects there. In Table 2, we provide the values of the economic damage, caused by the environmental pollutions in the municipal districts within the Zone. The maximal value of the damage, caused by the anthropogenic impact, was identified in Severobaikalsk, the minimal economic damage was identified in the North-Baikalsky region.

Table 2. The economic damage caused by the environmental pollutions in the municipal districts within the Zone (2014) (The sources: [37, 38]).

\begin{tabular}{|c|c|c|c|c|c|c|c|}
\hline \multirow[b]{2}{*}{$\begin{array}{l}\text { Municipal } \\
\text { districts }\end{array}$} & \multicolumn{7}{|c|}{ Types of economic damage } \\
\hline & $\begin{array}{l}\text { Caused by the } \\
\text { polluted } \\
\text { atmospheric air, } \\
\text { in thousand } \\
\text { rubles }\end{array}$ & $\begin{array}{l}\text { Caused by } \\
\text { polluted } \\
\text { water } \\
\text { bodies, in } \\
\text { thousand } \\
\text { rubles }\end{array}$ & $\begin{array}{l}\text { Caused by } \\
\text { the } \\
\text { industrial } \\
\text { waste, in } \\
\text { thousand } \\
\text { rubles }\end{array}$ & $\begin{array}{l}\text { Caused by } \\
\text { the } \\
\text { consumer } \\
\text { waste, in } \\
\text { thousand } \\
\text { rubles }\end{array}$ & $\begin{array}{l}\text { Caused by } \\
\text { the forest } \\
\text { products, in } \\
\text { thousand } \\
\text { rubles }\end{array}$ & $\begin{array}{c}\text { Caused by } \\
\text { discharged } \\
\text { pollutants } \\
\text { (phosphorus } \\
\text { and nitrogen), } \\
\text { in thousand } \\
\text { rubles }\end{array}$ & Total \\
\hline $\begin{array}{l}\text { Barguzinsk } \\
\text { y district }\end{array}$ & 297.54 & 0.00 & 604.38 & 3582.73 & 162.02 & 52.99 & 4699.66 \\
\hline $\begin{array}{l}\text { Kabansky } \\
\text { district }\end{array}$ & 73.00 & 178.28 & 2994.62 & 13002.03 & 17.05 & 201.98 & $\begin{array}{c}16466.9 \\
6\end{array}$ \\
\hline $\begin{array}{l}\text { Baikalsky } \\
\text { district }\end{array}$ & 198.12 & 126.46 & 1099.15 & 3732.54 & 43.25 & 53.71 & 5253.24 \\
\hline $\begin{array}{l}\text { North- } \\
\text { Baikalsky } \\
\text { district }\end{array}$ & 1775.83 & 71.50 & 1.33 & 3016.21 & 2.31 & 47.10 & 4914.28 \\
\hline $\begin{array}{l}\text { Severobaik } \\
\text { alsk }\end{array}$ & 5100.03 & 10249.34 & 69.51 & 4479.81 & 0.61 & 87.23 & $\begin{array}{c}19986.5 \\
3 \\
\end{array}$ \\
\hline
\end{tabular}

The analysis of the structure of the economic damage, caused by environmental pollutions, has proven the maximal damage value of the consumer waste, which is equal to $39.13 \%$. Major enterprises that pollute local water bodies, include three utility services providers; the amount of waste that they produce is equal to $16.57,4.25$ and 2.46 hypothetical tons, respectively.

The economic damage, caused by the industrial waste, is equal to $12.59 \%$. The maximal amount of industrial waste is generated by the rolled steel producer; its value is equal to 900 hypothetical tons (Kabansky district), the amount of waste, produced by forestry operations, is equal to 617.06 hypothetical tons (Barguzinsky district).

The majority of municipal districts within the Zone inflict insignificant economic damage, caused by environmental pollutions (See Table 3). New construction projects are acceptable in the majority of districts within the Zone.

Table 3. The clustering of the Zone's municipal districts based on the value of the economic damage caused by environmental pollutions.

\begin{tabular}{|c|c|c|c|}
\hline $\begin{array}{l}\text { Pollution } \\
\text { Intensity }\end{array}$ & $\begin{array}{l}\text { Economic Damage, } \\
\text { in k rubles }\end{array}$ & Municipal Units & Municipal Districts \\
\hline \multirow[t]{4}{*}{ Very low } & \multirow{4}{*}{$\begin{array}{c}0-1,000 \\
\text { (insignificant) }\end{array}$} & 11 rural villages & Kabansky \\
\hline & & $\begin{array}{l}3 \text { rural villages и } 1 \text { urban } \\
\text { settlement }\end{array}$ & North-Baikalsky \\
\hline & & 2 rural villages & Barguzinsky \\
\hline & & 1 rural village & Baikalsky \\
\hline \multirow[t]{2}{*}{ Low } & \multirow{2}{*}{$\begin{array}{l}1,001-2,000 \\
\quad(\text { low })\end{array}$} & 3 rural villages & Kabansky \\
\hline & & 1 rural villages & Baikalsky \\
\hline Moderate & $>2,001$ & 1 urban settlement and 1 & Kabansky \\
\hline
\end{tabular}




\begin{tabular}{|l|l|l|c|}
\hline \multirow{3}{*}{ (moderate) } & rural village & \\
\cline { 3 - 4 } & 1 rural villages & Baikalsky \\
\cline { 3 - 4 } & 1 urban settlement & Barguzinsky \\
\cline { 3 - 4 } & 1 urban settlement & North-Baikalsky \\
\cline { 3 - 4 } & The town of Severobaikalsk & \\
\hline
\end{tabular}

\section{Discussion of results}

The benchmarking of the anthropogenic impact against the environmental capacity has proven that the nature's potential has not been exceeded by the anthropogenic impact in any district. The value of the multiplication factor is below 1 in every district; therefore, the construction of new facilities is acceptable everywhere in the Zone. The smallest value of the anthropogenic impact/environmental capacity ratio has been identified in the Kabansky district, where the value of the environmental capacity is redundant, as in case of $\mathrm{Ke} \leq 0,3$ the environmental situation is considered as safe. Any high anthropogenic impact is caused by regular and irregular travelers and the seasonal migration of the population (local residents move to their country houses for summer seasons). The more residents the locality has, the more waste they generate. The population generates consumer waste and emits pollutants (nitrogen and phosphorus). However, the extensive dimensions of the area, occupied by the urban and rural settlements (12,009.7 square kilometers) in the Kabansky district, serve as the reason for its high environmental capacity.

In the Baikalsky district, the value of the multiplication factor is equal to 0.00007 ; therefore, new construction is acceptable here, as well. The maximal value of the anthropogenic impact (wastes, discharges, regular/irregular travelers) is identified in Turkinskoye rural settlement, which accommodates a special economic zone, specializing in the provision of touristic services (Russia has the total of five zones of this kind).

In Barguzinsky district, the value of the anthropogenic impact/environmental capacity ratio is equal to $111 / 10000$, and it means that any new construction is acceptable here. The highest value of the anthropogenic impact is identified in Ust-Barguzin, because it has a wood processing factory and therefore, it generates forestry waste. The relatively low value of the ratio is explained by the small area of the district under research (50.82 square kilometers).

The highest value of the ratio has been identified in Severobaikalsk (0.06696). Polluted atmospheric air represents the major constituent of the overall anthropogenic impact (79.2\%). The amount of pollutants, emitted into the atmosphere in 2014 , was equal to $23,244.85$ hypothetical tons [37]. The main sources of pollutions included electric power, gas, steam, and hot water producers. In 2014, the amount of polluted water, discharged into the local water bodies, was equal to 156.29 hypothetical tons [37]. Wastewater disposal companies represent the main pollutants of the local water bodies.

Table 4. Current, projected and normative values of emissions, broken down by the kettles of Lake Baikal (tons/year).

\begin{tabular}{|c|c|c|c|c|c|c|}
\hline \multirow{2}{*}{$\begin{array}{c}\text { The } \\
\text { Baikal } \\
\text { Kettles }\end{array}$} & $\begin{array}{c}\text { Emissions } \\
\text { specified } \\
\text { in the } \\
\text { effective } \\
\text { regulations }\end{array}$ & $\begin{array}{c}\text { Emissions, } \\
\text { calculated in } \\
2014\end{array}$ & $\begin{array}{l}\text { Projected } \\
\text { emissions }\end{array}$ & $\begin{array}{l}\text { Emissions } \\
\text { based on } \\
\text { effective } \\
\text { regulations }\end{array}$ & $\begin{array}{c}\text { Emissions, } \\
\text { calculated in } \\
2014\end{array}$ & $\begin{array}{c}\text { Projected } \\
\text { emissions }\end{array}$ \\
\hline $\begin{array}{l}\text { The } \\
\text { Northern } \\
\text { Kettle }\end{array}$ & 1,200 & 571.4 & 655.4 & 540 & 237.2 & 283.1 \\
\hline
\end{tabular}




\begin{tabular}{|l|c|c|c|c|c|c|}
$\begin{array}{l}\text { The } \\
\text { Middle } \\
\text { Kettle }\end{array}$ & $1,000.0$ & 33.2 & 43.7 & 500.0 & 39.2 & 58.9 \\
\hline $\begin{array}{l}\text { The } \\
\text { Southern } \\
\text { Kettle }\end{array}$ & 2,500 & 104.1 & 108.1 & 1,200 & 62.9 & 75.0 \\
\hline
\end{tabular}

The co-authors took advantage of the statistical reports (the air) for 2014 to assess the potential risks that could be caused by the pollutants emitted by stationary and mobile sources in the Zone. The co-authors also made projections in terms of emissions produced by the heating systems of residential houses and social facilities in the municipal districts. The calculations of their values were based on the recommendations issued by the Research Institute of the Atmosphere [42]. Table 3 contains the current and projected values of emissions broken down by the kettles of Lake Baikal and acceptable emission values according to Regulations 2010 [24].The benchmarking of the values, provided in Table 3, has proven that the rise of the values of emissions, specified in the effective regulations, is acceptable in the Zone; therefore, we can make a conclusion that new infrastructural facilities can be constructed there.

\section{Conclusions}

Recently, methods of multi-criteria analysis have been widely used both in the environmental research and in any projects that require decision-making in respect of varied issues of socioeconomic development. In Russia, these methods are particularly frequently employed to assess the influence, produced by mining and power generation (including nuclear power) companies, and to analyze their locations, because the implementation of these long-term and costly projects requires the multi-criteria analysis of alternative options.

We have developed several methodological approaches towards the multi-criteria analysis that serves as the basis for the integral ranking of areas. Our methodologies rest on the assessment of the environmental capacity of the natural environment and the anthropogenic impact, as their benchmarking represents a relevant objective of environmentally sustainable development of local areas. The results serve as the criteria of acceptance of new construction facilities in the Zone.

The recommendations on the compilation of the list of ecologically acceptable types of activities are consistent with the regulatory requirements, applicable to the Zone; to some extent, these recommendations may ease the social and economic tensions in the municipal settlements of the shoreline and reduce the adverse impact produced on the ecosystems of the local forests and water bodies.

\section{References}

1. A.L. Bobrov, K.V. Papenov, Herald of the Moscow University. Series 6. Economics 4, 101-118 (2013)

2. S.N. Bobylev, O.E. Medvedeva, Ecology and Economy. Handbook of the Regional Environmental Policy (Akropol Publ., Moscow, 2004)

3. N.V. Pakhomova, A. Endres, K. Richter, Environmental Management (Piter Publ., St. Petersburg, 2003)

4. N.N. Lukyanchikov, I.M. Potravnyy, Economics and Organization of Environmental Management (UNITI-DANA Publ., Moscow, 2002) 
5. Federal Law № $94-$ FZ of May 01, 1999

6. RF Government Regulation \# 661 of September 06, 2000. Collection of Legislative Acts of the Russian Federation 49(2), 5256 (2006)

7. RF Government Executive Order of November 27, 2006 №1641-p “About the Borders of the Baikal Natural Area"

8. RF Government Executive Order of March 05, 2015 №368-p “About the Borders of Lake Baikal Water Protective Zone"

9. RF Government Executive Order of August 30, 2001 №643 "On the Approval of the List of Activities, Prohibited in the Central Ecological Zone of the Baikal Natural Area"

10. I.V. Shishkina, D.V. Matyushina, Construction and Restructuring Journal 5, 61 (2015)

11. S.I. Nosov, O.A. Antipov, Economy and Entrepreneurship Journal 12-4(65-4), 913-916 (2015)

12. A.K. Toulokhonov, Bulletin of the Russian Academy of Sciences, Geographical Series 1, 37-41 (2010)

13. E.Zh. Garmayev, V.S. Batomunkuyev, B.O. Gomboyev, I.D. Ulzetuyeva, I.D. Sanzhuyeva, Geography and Natural Resources 5, 234-238 (2016)

14. E.G. Nechayeva, N.D. Davydova, Geography and Natural Resources 2, 164-171 (2010)

15. T.V. Khotzher, L.M. Sorokovikova, V.N. Sinyukovich, I.V. Tomberg, I.I. Marinaite, Geography and Natural Resources 1, 37-45 (2015)

16. T. Zabortseva, Questiones Geographicae 30(2), 81-86 (2011)

17. I.A. Belozertseva, I.B. Vorobjeva, N.V. Vlasova, D.N. Lopatina, M.S. Janchuk, Water resources 3, 471-484 (2017)

18. A.D. Sanzheev, A.T. Solovova, Bulletin of the Irkutsk State University. Earth Sciences Series 8, 119-132 (2014)

19. L.B.-Zh. Maksanova, Bulletin of the National Academy of Tourism 2(38), 12-16 (2016)

20. G. Yongfei, L. Honglin, L. Guixiang, Environmental Science and Pollution Research, 1-15 (2017) https://doi.org/10.1007/s11356-017-0113-0

21. R. Siew, Building Research and Information 43(2), 160-169 (2015)

22. I. Geipele, L. Kaushkale, Works of the 7th Science Conf. to the 110th Anniversary of the Plekhanov Russian University of Economics "Contemporary Problems of Project Management in the Investment and Construction Industry and Environmental Management", 145-150 (2017)

23. The Recreational Capacity of Natural Landscapes. Baikal. Atlas. (Federal Service for Geodesy and Mapmaking of Russia, Moscow, 1993)

24. Order of the Ministry of Natural Resources and Ecology of the Russian Federation of March 05, 2010 № 63 http://www.garant.ru/products/ipo/prime/doc/12076656/

25. T.B. Bardakhanova, A.S. Mikheeva, S.D. Pountsoukova, B.L. Radnayev, Methodology for Identification of Ecological Expenditures of a Region (Buryat Research Centre, Siberian Section of the Russian Academy of Sciences, Ulan-Ude, 2001)

26. O.F. Blavatsky, L.G. Melina, A.F. Yakovlev, Economy and Quality of the Natural Environment (Gidrometeoizdat Publ., Leningrad, 1984)

27. L.G. Melnik, Fundamentals of Development (Universitetskaya Kniga Publ., 2006) 
28. I.M. Potravnyy, K.P. Kolotyrin, I.B. Gengut, The Economics of Contemporary Russia 2(77), 78-89 (2017)

29. O.V. Prokopenko, Works of the International Science and Practical Conference 2, 188189 (2013)

30. S.D. Pountsoukova, The System Approach towards the Assessment of the Natural Capital 6, 155-158 (2010)

31. T.O. Tagayeva, L.K. Kazantseva, Interexpo GEO-Sibir Publ. 1(3), 82-88 (2012)

32. S.N. Vasilyev, The Modeling and Management of the Processes of Regional Development (Fizmatlit Publ., Moscow, 2001)

33. V.N. Gourman, Economics, and Management 2(3), 4-7 (2011)

34. N.M. Sysoyeva, O.V. Sysoyeva, Problems of the Entrepreneurship Development in the Coastal Area of Lake Baikal 5, 144-150 (2016)

35. N.G. Miloradova, A.D. Ishkov, Procedia Engineering 117, 246-251 (2015)

36. Z.I. Ivanova, O.V. Yudenkova, A.D. Ishkov, E.A. Shnyrenkov, International Education Studies 8(5), 232-239 (2015)

37. Protection of the Environment and Natural Resources. Collection of Statistical Data № 06-02-08 (Buryatstat Publ., Ulan-Ude, 2016)

38. Districts of Buryatia. Collection of Statistical Data № 02-6 (Goskomstat RB Publ., Ulan-Ude, 2016)

39. The report on the Research Project "Protection of Lake Baikal and the socioeconomic development of the Baikal natural area for 2012 - 2020”. State Registration № 114121970060 (2016)

40. T.A. Akimova, Yu.N. Moseikin, The Economics of Sustainable Development (Ekonomika Publ., Moscow, 2009)

41. The Methodology for the Assessment of Any Prevented Ecological Damage, http://docs.cntd.ru/document/1200035561

42. Methodology for the Assessment of Hazardous Substances Emitted into the Atmosphere in the Course of the Fuel Combustion in Boilers Capable of Generating, at least, 30 tons of Steam per hour, or, at least, 20 Gcal per hour (1999) 